\author{
Review Article \\ www.ijrap.net (ISSN:2229-3566)
}

\title{
A REVIEW ON STERILIZATION: AN AYURVEDIC APPROACH
}

P. V. Vijay Guptha ${ }^{1 *}$, Syeda Ather Fathima ${ }^{2}$, Shivalingappa J. Arakeri ${ }^{3}$, Mohasin Kadegaon ${ }^{4}$, Geethanjali Hiremath ${ }^{4}$

${ }^{1}$ PG Scholar, Department of Shalya Tantra, Taranath Government Ayurvedic Medical College, Ballari,

Karnataka, India

${ }^{2}$ Principal, Taranath Government Ayurvedic Medical College, Ballari, Karnataka, India

${ }^{3}$ Associate Professor and HOD, Department of Shalya Tantra, Taranath Government Ayurvedic Medical College, Ballari, Karnataka, India

${ }^{4}$ Assistant Professor, Department of Shalya Tantra, Taranath Government Ayurvedic Medical College, Ballari, Karnataka, India

Received on: 10/06/20 Accepted on: 10/07/20

*Corresponding author
E-mail: p.v.vijayguptha.01@gmail.com

DOI: 10.7897/2277-4343.1104124

\begin{abstract}
Sterilization is a process by which an article, surface or medium is freed of all living microorganisms either in the vegetative or spore state. In Ayurveda Nirjantukarana is explained and are scattered in Samhitas. Various methods like Dhoopana, Prakshalana, Agnitapana, exposure to sunlight etc, are explained in sterilization of Shastragara, Vranitagara, Kumaragara, Sutikagara, Bandhana Dravya, Shastra etc. Drugs and Gana used for sterilization have Kandugana, kushtagana, Vranashodhana and Krimighana properties. Purification of air by Nyagrodha etc, herbs in HOMA not only purifies air, even gives spiritual and psychosomatic health to the people. Herbs and stone used in water purification have Krimihara, Nirvishikarana action along with giving water medicinal value. Drugs and methods need to be evaluated on modern parameters so that it receives global acceptance and can be confidently adopted in the clinical practice.
\end{abstract}

Keywords: Nirjantukarana, Kandugana, Kushtagana, Vranashodhana, Krimighana, Nirvishikarana

\section{INTRODUCTION}

Sterilization is a process by which an article, surface or medium is freed of all living microorganisms either in the vegetative or spore state. The air around us is filled with millions of microorganisms (bacteria, fungi, protozoa, and virus).

In Ayurveda term Krimi is used in broader sense, it includes pathogenic and non-pathogenic organisms covering wide range of infection and infestation. Ancient science stated the various methods for disinfection and sterilization which have been used at that time. Sushruta explained sterilization (Raksha karma/Nirjantukarana) methods to manage the surgical diseases to avoid post-op complications especially the secondary infections. Sushruta used different methods for sterilization like Dhoopana, Prakshalana, Agnitapana and exposure to sunlight etc, all these methods are scattered in the Sushruta Samhita.

In Janapadodhwamsa where the land, air, water gets vitiated and leading to various diseases. The methods said to purify the vitiated air and water can be used in the sterilization of OT, instruments, cloths, Vranitagara, Kumaragara, Sutikagara etc.

\section{Air and Water Purification}

In Ayurveda Rakshoghna karma, this includes various ancient sterilization procedures still in practice like performing HOMA during puja. In ancient time there was more air and water borne diseases, so given more importance to it.
Air purification is by HOMA like Agnihotra Homa where drugs Khadira, Palasha, Devadaru, Bilva, Nyagrodha, Udumbara, Aswatha and Ghrita are used as havisha ${ }^{1}$.

Water by heating, drugs like Kataka, Chandrakanta mani $^{2}$ etc

\section{Dhoopana type of Raksha karma}

\section{Dhoopana for Vrana}

Vrana with lakshana, excessive discharge (pus/serosanguinous), foul smell, itching, pain, redness, burning sensation etc, indicate the presence of active infection. Dhoopana using Krimihara dravya reduces the above lakshana suggesting its Nirjantukarana action.

Shriveshtaka, Sarjarasa, Sarala, Devadaruni, Salasaradi gana is used for Vrana dhoopana ${ }^{3}$.

\section{Dhoopana for Agara (operation theatre/wards)}

Regarding purification of Shastragara, Vranitagara, Sutikagara, Kumaragara criterions are as follows; they should be devoid of direct sunlight, air entry. But proper ventilation should be maintained. It should be devoid of dust, smoke.

- Dhoopana yoga used to purify the room;

- Sarshapa, Nimba, Ghrita, Lavana are used to fumigate twice daily for 10 days $^{4}$.

- Guggulu, Agaru, Sarjarasa, Vacha, Gourasarshapa, Lavana, Nimba patra, Ghrita 5 . 


\section{Sterilization of Bandhana Dravya}

Vagbhata explained fumigation method or exposure to sunlight of the dravya for Nirjantukarana of bandhana dravyas.

Suchi sUkShmadRuDhA paTTAH kavalyaH savikeSikAH dhUpitAH mRudavaH SlakShNA nirvallka vraNe hitAH $\|$ A.H.Su 29/29

\section{Sterilization in Shastra Karma}

Incision is taken after proper heating of Shastra (instruments) otherwise paka (pus formation/infection/inflammation) takes place.

Agnitaptena shastreNa chindyAt, anyathA ataptashastracchedan e pAkabhayaM syAt $\|$

(Su.Chi 2/46)

Heating the Shastra will kill the krimi (microorganisms) by coagulation of the protein avoiding secondary infection.

\section{Sterilization in Paschatkarma}

Kashaya Prakshalana, Dhoopana, Vrana Bandhana and mantra to prevent secondary infection. Explained many group of drugs (both herbal and mineral) having kandughna, Kushthaghna and Vranashodhana properties for nirjantukarna. ${ }^{6}$

\section{Kashaya for Prakshalana}

Various kashaya are used to purify Vrana like

Panchavalkala kashaya,

Triphala kashaya

Sursadi gana kashaya

Aragwadhadi gana kashaya

Purana ghrita etc. ${ }^{7}$

\section{Gana/Dashemani (Group of drugs)}

Aragwadhadi gana

Arkadi gana

Sursadi gana

Eladi gana

Patoladi gana

Trapvadi gana

Lakshadi gana

Kandughna Dashemani

Krimihara

Vishaghna

Kushthaghna

Asanadi gana

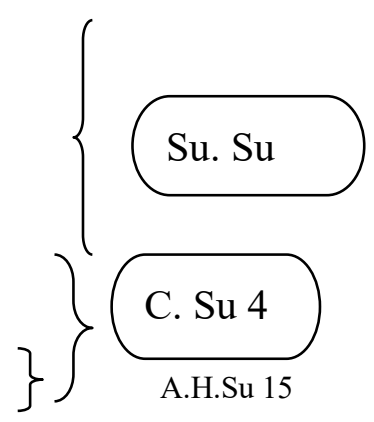

\section{Raksha karma}

Drugs for Murdni dharana are Padmacharini, Guha (Prishniparni), Atiguha (Shalaparni), Vacha ${ }^{8}$ etc,.

Brahmi Indrayani, Jeevaka, Rishabaka and Vacha are used to tie at neck, head, hands ${ }^{9}$ etc.

Even the Karna Vyadhana is also having effect of Raksha karma. rakShAbhUShaNanimittaM bAlasya karNau vidhyete $\|$ (Su. Su 16/3)
Reciting mantra for Raksha karma.

kRutyAnAM pratighAtArthaM tathA rakShobhayasya ca | rakShAkarma kariShyAmi brahmA tadanumanyatAm \|

(Su. Su 5/20)

In Shashti Upakrama Sushruta mentioned the importance of Raksha karma and advised to follow the guidelines of do's and don'ts for patient, attender and doctor.

nishAcarebhyo rakShyastu nityameva kShatAturaH | rakShAvidhAnairuddiShTairyamaiH saniyamaistathA \| (Su. Chi 1/133)

\section{DISCUSSION}

In present scenario world is facing a stressful situation Covid 19. World needs a safe environment, here is scope of Ayurvedic way of Raksha karma/Nirjantukarana methods. Need of time is, to evaluate Raksha karma/Nirjantukarana methods on the required parameter and have clarity of thought, helps in practical implementation. Acharya Sushruta explained Raksha karma in Shashti Upakrama said to manage Vrana. Not only given importance to Dhoopana, Prakshalana etc, but also guidelines for doctor, patient and attenders like yama and niyama. These have both psychosomatic and medicinal importance. Sushruta explained the ways to prevent secondary infection right from the preoperative till completion of postoperative surgical management. There are ways to prevent secondary infection, still holds good practically. Selection and implementation of these is necessary, which have medicinal value too.

\section{CONCLUSION}

Sushruta's concepts of sterilization are as effective as in those days. Need is to evaluate them on modern parameters for its globalization.

It is necessary to have a detailed study of drugs used in sterilization procedure for its mode of action and antimicrobial action. Evaluate its vital role in prevention, transmission and killing the microorganisms' responsible for infectious contagious diseases.

\section{REFERENCES}

1. Acharya Sushruta, Sushruta Samhita. Yadavji Trikamji, Editor, Sutra Sthana, Shisyopanayaneeya adhyaya, $1^{\text {st }}$ edition. Varanasi: Chaukhambha Sanskrit Sansthana, verse - 4; 2014. p. 11.

2. Acharya Sushruta, Sushruta Samhita. Yadavji Trikamji, Editor, Sutra Sthana, Dravadravyadhi adhyaya, $1^{\text {st }}$ edition. Varanasi: Chaukhambha Sanskrit Sansthana, verse - 4 and 27; 2014. p. 198-199.

3. Acharya Sushruta, Sushruta Samhita. Yadavji Trikamji, Editor, Sutra Sthana, Mishraka adhyaya, $1^{\text {st }}$ edition. Varanasi: Chaukhambha Sanskrit Sansthana, verse - 21; 2014. p. 162.

4. Acharya Sushruta, Sushruta Samhita. Yadavji Trikamji, Editor, Sutra Sthana, Vranitopasaneeya adhyaya, $1^{\text {st }}$ edition. Varanasi: Chaukhambha Sanskrit Sansthana, verse -.28; 2014. p. 92.

5. Acharya Sushruta, Sushruta Samhita. Yadavji Trikamji, Editor, Sutra Sthana, Agropaharaneeya adhyaya, $1^{\text {st }}$ edition. Varanasi: Chaukhambha Sanskrit Sansthana, verse - 18; 2014. p. 21.

6. Acharya Sushruta, Sushruta Samhita. Yadavji Trikamji, Editor, Sutra Sthana, Agropaharaneeya adhyaya, $1^{\text {st }}$ edition. 
Varanasi: Chaukhambha Sanskrit Sansthana, verse - 17; 2014. p.21.

7. Acharya Sushruta, Sushruta Samhita. Yadavji Trikamji, Editor, Sutra Sthana, Mishraka adhyaya, $1^{\text {st }}$ edition. Varanasi: Chaukhambha Sanskrit Sansthana, verse - 4; 2014. p. 160163.

8. Acharya Vagbhata, Ashtanga Hridaya translated by Dr. Brahmanand Tripathi, Sutra Sthana Shastrakarmavidir adhyaya, Reprinted:. Delhi: Chaukhamba Sanskrit Pratishthan, verse - 30-31; 2019. p. 320.

9. Acharya Vagbhata, Ashtanga Hridaya translated by Dr. Brahmanand Tripathi, Uttara tantra Baalopcharneeya adhyaya, Reprinted. Delhi: Chaukhamba Sanskrit Pratishthan, verse - 27; 2019. p. 880.

\section{Cite this article as:}

P. V. Vijay Guptha et al. A Review on Sterilization: An Ayurvedic approach. Int. J. Res. Ayurveda Pharm. 2020;11(4):235-237 $\quad$ http://dx.doi.org/10.7897/2277-

Source of support: Nil, Conflict of interest: None Declared

Disclaimer: IJRAP is solely owned by Moksha Publishing House - A non-profit publishing house, dedicated to publishing quality research, while every effort has been taken to verify the accuracy of the content published in our Journal. IJRAP cannot accept any responsibility or liability for the site content and articles published. The views expressed in articles by our contributing authors are not necessarily those of IJRAP editor or editorial board members. 